\title{
CHEMICAL ENVIRONMENT OF WATER MOLECULES ADSORBED ON THE ANATASE SURFACE: QUANTUM CHEMICAL STUDY
}

\author{
Chuiko Institute of Surface Chemistry of National Academy of Sciences of Ukraine \\ 17 General Naumov Str., Kyiv, 03164, Ukraine, E-mail: olsmirnova2001@ukr.net
}

\begin{abstract}
Theoretical studies of the interactions of an oxygen molecule with the surface of a solid phase are of great importance for understanding the mechanisms of reactions involving oxygen on a solid surface. In this work, the spatial and electronic structure of oxygen defects and nitrogen impurity centers of the anatase surface and their manifestation in water adsorption are investigated. The anatase surface was simulated for by clusters of the composition $\mathrm{Ti}_{14} \mathrm{H}_{22} \mathrm{O}_{39}$ (defect-free face (001)), $\mathrm{Ti}_{14} \mathrm{H}_{22} \mathrm{O}_{38}$ (surface with oxygen vacancy), and $\mathrm{Ti}_{14} \mathrm{H}_{22} \mathrm{~N}_{2} \mathrm{O}_{36}$ (surface with both oxygen vacancy and incorporated nitrogen), terminated with boundary hydrogen atoms.

Calculations on the total energy of the optimized geometric structures of the model TiO $\mathrm{O}_{2}$ clusters and on the corresponding theoretical XPS spectra were performed using the density functional theory (DFT) method and the B3LYP hybrid functional with an extended valence-split basis set 6-31G $(d, p)$.

In the XPS spectra of O1s, each peak can be attributed to a specific type of oxygen atoms in the initial structure, dependent on their coordination environment. The substitution of nitrogen atoms for oxygen ones leads to a complication of the spectrum. Simultaneous replacement of nitrogen atoms for oxygen ones and presence of an oxygen vacancy leads to further complication of the XPS spectrum.

The different structure of the adsorption complexes of water molecules on the anatase surface formed due to the $\mathrm{HOH} \cdots \mathrm{O}$ hydrogen bond (this displaces by $0.05 \mathrm{eV}$ all the peaks in the XPS spectrum) or the coordination bond $\mathrm{Ti}^{\cdots} \mathrm{OH}_{2}$ has been also considered.

Based on the analysis of theoretical results, the role of various forms of defects in the adsorption of water on the anatase surface is considered.

The results of quantum chemical studies of molecular models simulated for the bulk and surface of titanium dioxide are compared with the literature data available.
\end{abstract}

Keywords: anatase, oxygen defect, nitrogen impurity, water adsorption, XPS spectra, quantum chemical density functional theory (DFT) method, cluster models

\section{INTRODUCTION}

Interest has grown significantly to the theoretical studies on the interaction of an oxygen molecule, its ground state being a triplet diradical, with a solid-phase surface. The results of such studies are of fundamental importance for both adsorption and catalysis, for the general theory of corrosion of metals (they let it possible at least to slow down the corresponding reactions). Of great importance are studies on the interaction of an $\mathrm{O}_{2}$ molecule with a widely used semiconductor material, namely titanium dioxide; its forbidden band makes it possible to use only a relatively small range of ultraviolet radiation from the sun. The formation of nonstoichiometric areas on the $\mathrm{TiO}_{2}$ surface, due to impurity centers, removal of oxygen atoms, and adsorption of atomic and molecular oxygen, makes it possible to reduce the width of the forbidden band of $\mathrm{TiO}_{2}$ prior to its shift to the visible range of electromagnetic radiation.

The photochemistry of the ultraviolet absorption region of molecular oxygen $\mathrm{O}_{2}$ is of interest for chemical physics, photobiochemistry, and many other scientific fields [1].

Molecular oxygen very weakly absorbs radiation throughout the entire spectral range from infrared to ultraviolet, but the presence and influence of the molecular environment make possible the existence of molecules of singlet oxygen $\mathrm{O}_{2}\left({ }^{1} \Delta_{\mathrm{g}}^{-}\right)$, the formation of which is forbidden during photoexcitation of "isolated" $\mathrm{O}_{2}$ molecules. $\mathrm{O}_{2}$ molecules, due to their high reactivity, play a key role in natural photobiological and photochemical processes; therefore, a detailed study on the mechanisms of its formation is believed to be a fight-to-date scientific research task. Thus, examining the 
formation of singlet oxygen upon photoexcitation of a weakly bound $\mathrm{X}^{\cdots} \mathrm{O}_{2}(\mathrm{X}$ active surface sites) complex is not only fundamental, but also of practical interest, since this process is a new way of generating $\mathrm{O}_{2}$ molecules. This process provides a new mechanism for photo-oxidation of various molecules in a condensed medium, and can also be used in UV air purification, in photocatalysis, photobiology, and medicine. Theoretical study on the processes of interaction between molecular oxygen and surface, for example, that of $\mathrm{TiO}_{2}$, is associated with the corresponding complications caused by the singlet state of both the surface itself and respective adsorption complex. There is a need to expand the generally accepted cluster model (CM) of adsorption, which involves a theoretical calculation of the cross section of only one potential energy surface (PES), which, as a rule, corresponds to the singlet ground electronic state. In the case, when the $\mathrm{O}_{2}$ molecule reacts in the triplet state, it becomes necessary to calculate the cross section of another PES, which characterizes the triplet state of the cluster consisting of an $\mathrm{O}_{2}$ molecule and a fragment of both surface and adjacent bulk phase of the $\mathrm{TiO}_{2}$ crystal.

Titanium dioxide belongs to the class of transition metal oxides, in nature it occurs with the structures of anatase (tetragonal), brookite (rhombic), rutile (tetragonal), less often with monoclinic $\mathrm{TiO}_{2}$ structure. Differences in the crystal lattices of titanium dioxide cause differences in density, mass and in the electronic band structure of titanium dioxide. The width of the band gap for the anatase structure is $3.2 \mathrm{eV}$, and for rutile $-3.0 \mathrm{eV}[2]$.

The photocatalytic activity of titania nanoparticles was found to increase with a decrease in their diameter for both anatase and rutile modifications. When measuring their absorption spectra, an increase in their diameter was shown to shift the maximum of the absorption spectrum from the ultraviolet region to the long-wavelength part of the electromagnetic scale [3].

In previous article [4], the spatial structure and electronic structure of defect and impurity centers of polymorphous modifications of titanium dioxide and their manifestation in adsorption, catalytic and photocatalytic processes were analyzed. Here, we analyze the densities of states of oxygen atoms in titania matrices (parent and containing impurities of nitrogen and/or oxygen vacancies).

\section{METHODS}

The aim of the studies was to calculate the density of states of cluster models for the anatase surface (pure, nitrogen-substituted, and containing oxygen defects). Theoretical densities of states can be compared with the experimental spectra of XPS. As a result, we can determine the effect of the local environment of oxygen atoms on the chemical shift relative to their structurally nonequivalent crystallographic positions [4].

The H-terminated clusters that simulate the surface of an ideal anatase crystal, as well as the surface with an oxygen vacancy on the face (001) were considered. The defect-free face (001) of anatase was modeled by the cluster of the gross formula $\mathrm{Ti}_{14} \mathrm{H}_{22} \mathrm{O}_{39}$ which contains 7 surface five-fold coordinated titanium atoms. The presence of an oxygen vacancy was reproduced by the cluster $\mathrm{Ti}_{14} \mathrm{H}_{22} \mathrm{O}_{38}$, which is obtained from the former by removing of a twofold coordinated surface oxygen atom as well as the surface with both oxygen vacancy and incorporated nitrogen was mimicked by $\mathrm{Ti}_{14} \mathrm{H}_{22} \mathrm{~N}_{2} \mathrm{O}_{36}$ cluster model.

Quantum chemical calculations were carried out within the frameworks of the so-called cluster approximation [5]. Computations on the total energy values of the optimized geometrical structures of $\mathrm{TiO}_{2}$ cluster models including 14 titanium atoms $\left(\mathrm{Ti}_{14} \mathrm{H}_{22} \mathrm{O}_{39}\right)$ and of relative models containing impurities of nitrogen and/or oxygen vacancies were performed using density functional theory (DFT) method [6] and the hybrid B3LYP [7] functional with extended valence-split basis set $6-31 \mathrm{G}(\mathrm{d}, \mathrm{p})$. Calculations were carried out by means of the software package PC GAMESS [8] (version Firefly 8.1.0 by A. Granovsky, http://classic.chem.msu.su/ gran/firefly/index.html). The densities of states were designed based on the quantum chemical results with use of the Spectra Builder 2.4 program package [9] earlier used by us in the article [10].

\section{RESULTS AND DISCUSSION}

The experimental XPS spectra of initial (pure) titania matrix and of related oxygenvacancy and/or of nitrogen-impurity samples were examined and discussed in work [4]. Here, 
let us make an attempt to evaluate interrelations between the model structures and their calculated XPS spectra (Figs. 1-4).

All the oxygen atoms in the parent structure (Fig. 1) can be divided into some groups according to their coordination environment (2- and 3-coordinated) and to chemical nature of the second and third neighbors. Five $\mathrm{O} 1 s$ peaks one can observe in the XPS spectrum calculated for this cluster model (near $521 \mathrm{eV}$ ). Every peak can be assigned to a definite type of $\mathrm{O}$ atoms depicted in the inset in Fig. 1.

Elimination of an oxygen atom from the titania matrix results in an divergence between 2-coordinated and 3-coordinated oxygen atoms (the split peak at 521.44 and $521.28 \mathrm{eV}$ respectively, see Fig. 2).

Dinitrogen substitution for oxygen atoms results in the complication of the spectrum (at least 12 peaks can be observed). Nevertheless, 2 new peaks appear near $523 \mathrm{eV}(522.87$ and $523.28 \mathrm{eV}$ ) related to 3 -coordinated oxygen atoms (Fig. 3).

Simultaneous dinitrogen substitution for oxygen atoms and oxygen vacancy leads to futher complication of the XPS spectrum (15 peaks can be distinguished, including a pair near $523 \mathrm{eV}$, namely 522.60 and $522.74 \mathrm{eV}$, see Fig. 4).

The different structure of water molecule adsorption complexes have been considered, one of them being due to formation of a hydrogen bond $\mathrm{HOH} \cdots \mathrm{O}$ whereas another is characterized by a coordination bond $\mathrm{Ti}^{\cdots} \mathrm{OH}_{2}$ (Fig. 5).

In the first case, a shift for approximately $0.05 \mathrm{eV}$ takes place of all the peaks in the XPS spectrum calculated for the adsorption complex though the spectrum is somewhat broadened and as a whole keeps its image.
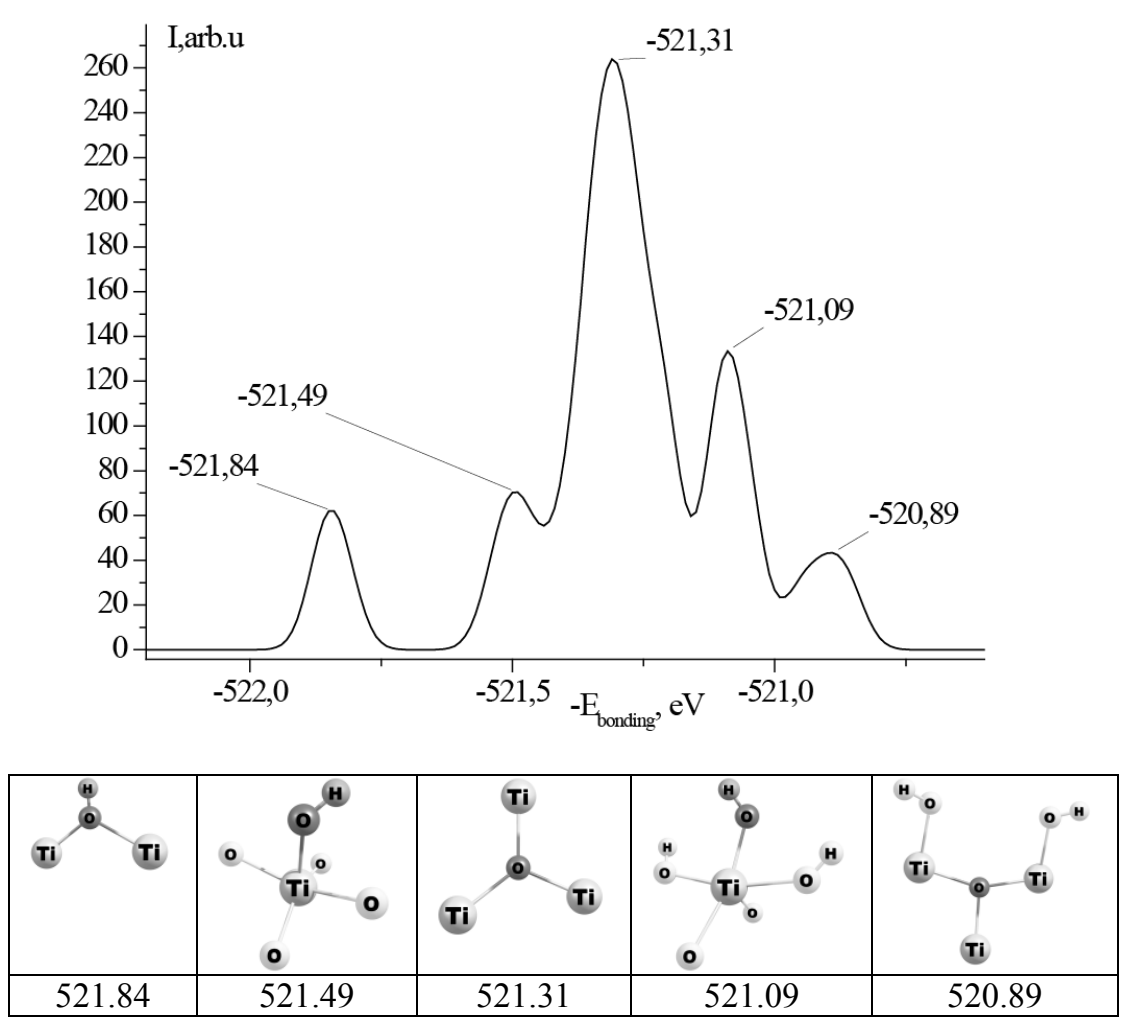

Fig. 1. Cluster model and calculation XPS spectra for parent structure titania surface $\mathrm{Ti}_{14} \mathrm{H}_{22} \mathrm{O}_{39}$ 


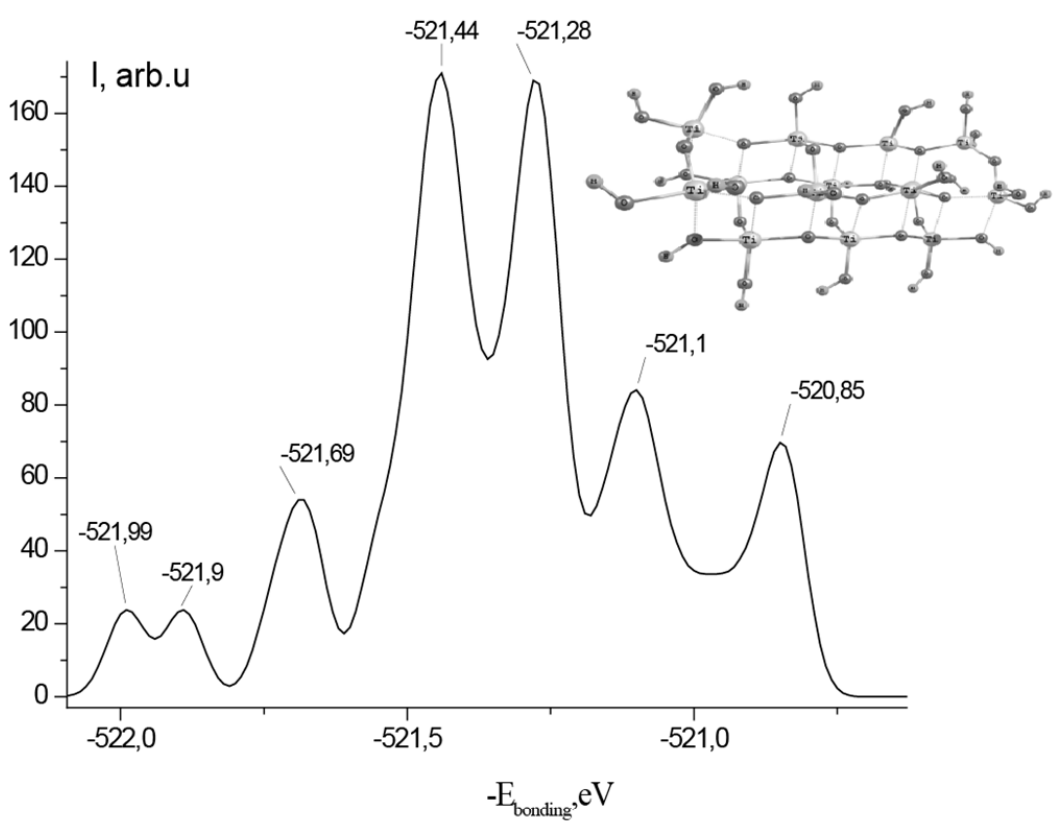

Fig. 2. Cluster model and calculation XPS spectra for structure with oxygen vacancy $\mathrm{Ti}_{14} \mathrm{H}_{22} \mathrm{O}_{38}$
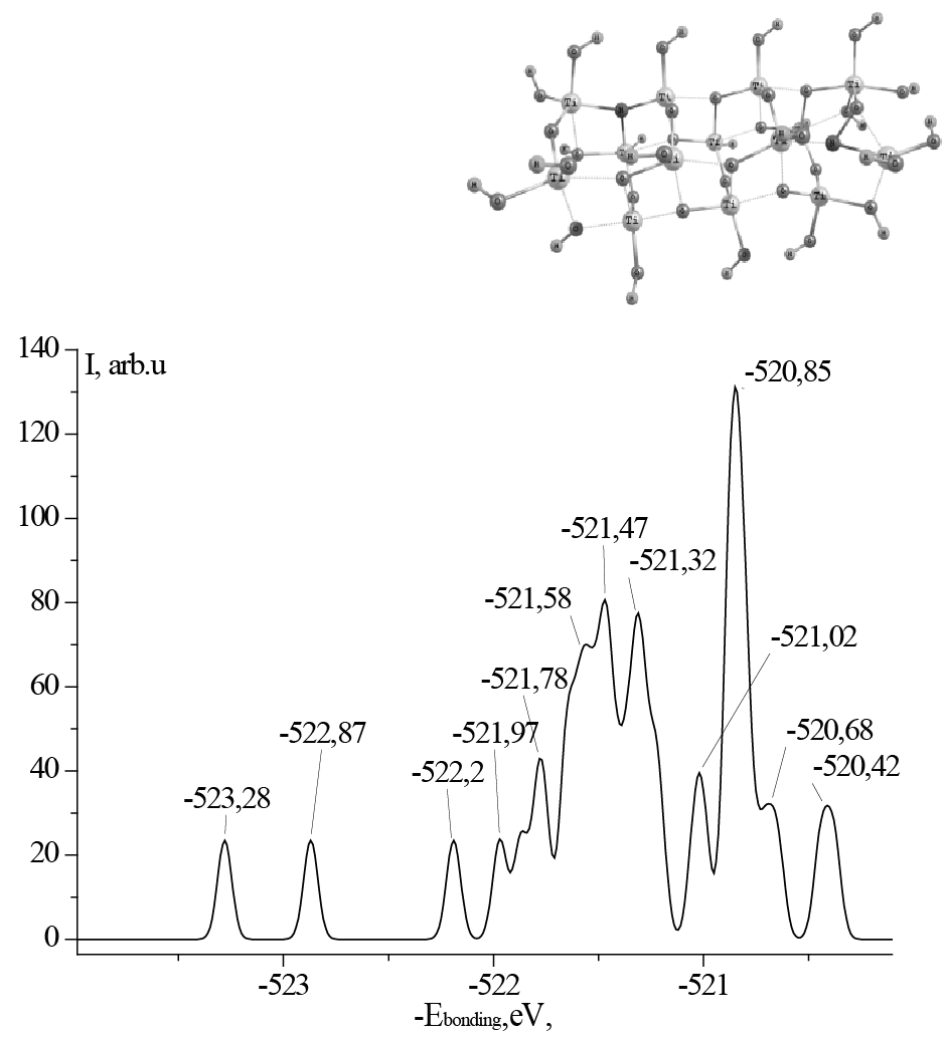

Fig. 3. Cluster model and calculation XPS spectra for structure with dinitrogen substitution for oxygen atoms $\mathrm{Ti}_{14} \mathrm{~N}_{2} \mathrm{H}_{22} \mathrm{O}_{37}$ 

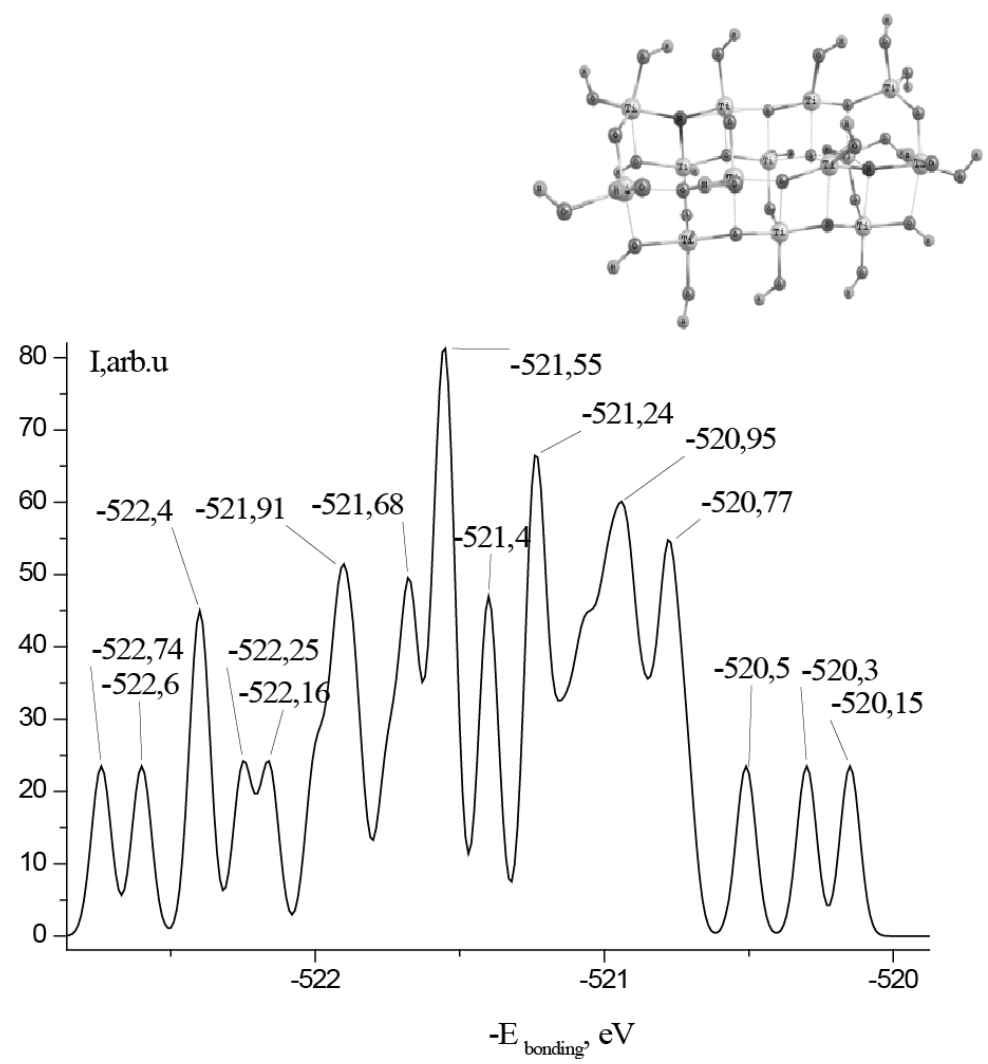

Fig. 4. Cluster model and calculation XPS spectra for combined structure with simultaneous dinitrogen substitution for oxygen atoms and oxygen vacancy $\mathrm{Ti}_{14} \mathrm{~N}_{2} \mathrm{H}_{22} \mathrm{O}_{36}$

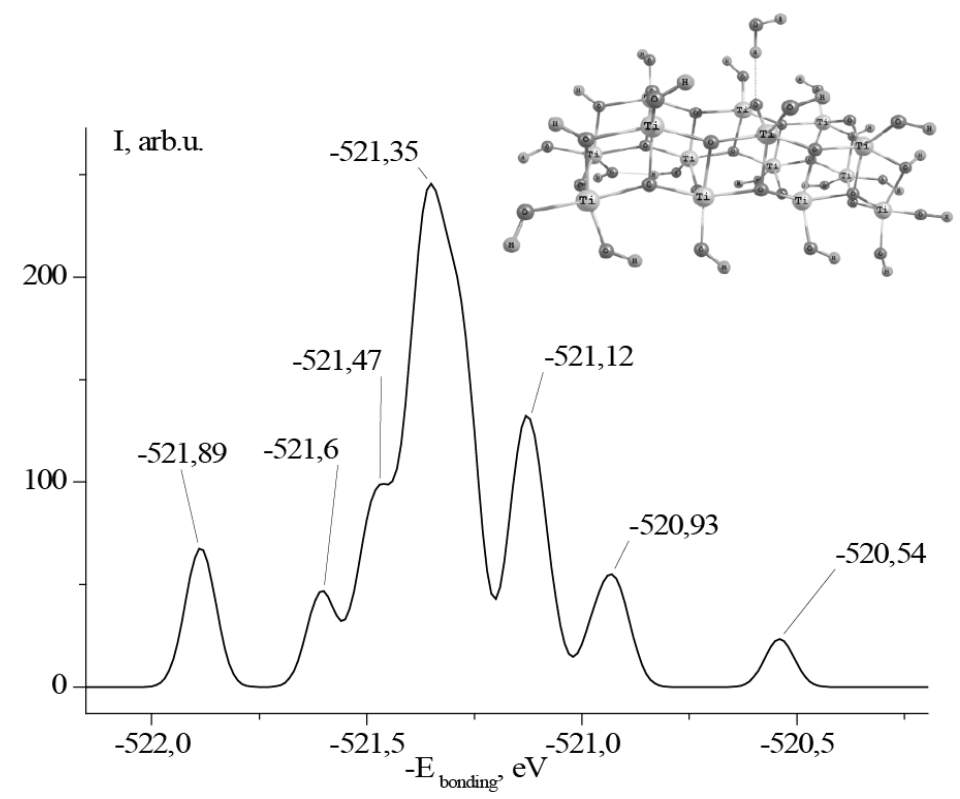

Fig. 5. Cluster model and calculation XPS spectra for adsorption of water molecules on titania surfaces. $E_{\mathrm{a}}=-36 \mathrm{~kJ} / \mathrm{mol}$ 


\section{CONCLUSIONS}

An analysis of the results of quantum chemical calculations gives evidence that the chemical environment of water molecules adsorbed on anatase surface is reflected in experimental XPS spectra. The adsorption of water molecules leads to a bathochromic shift of all the peaks $\mathrm{O} 1 s$ in the spectra. The presence of oxygen defects and nitrogen impurities results in complication of the spectra and in appearance of $\mathrm{O} 1 s$ double peaks.

\title{
Ідентифікація хімічного оточення молекул води, адсорбованих на поверхні анатазу: квантовохімічні розрахунки
}

\author{
О.В. Смірнова, А.Г. Гребенюк, В.В. Лобанов
}

Інститут хімії поверхні ім. О.О. Чуйка Наџіональної академії наук Украӥни вул. Генерала Наумова, 17, Київ, 03164, Україна, olsmirnova2001@ukr.net

Теоретичні дослідження взаємодї молекули кисню з поверхнею твердої фази мають велике значення для розуміння механізмів реакиій за участю $\mathrm{O}_{2}$ на твердій поверхні. $У$ иій роботі досліджена просторова $i$ електронна структура кисневих дефектів і азотних домішкових иентрів поверхні анатазу та їхні прояви в адсорбиії води. Поверхня анатаза моделювалася кластерами складу $\mathrm{Ti}_{14} \mathrm{H}_{22} \mathrm{O}_{39}$ (бездефектна грань (001)), $\mathrm{Ti}_{14} \mathrm{H}_{22} \mathrm{O}_{38}$ (поверхня з кисневою вакансією) $т а \mathrm{Ti}_{14} \mathrm{H}_{22} \mathrm{~N}_{2} \mathrm{O}_{36}$ (поверхня з кисневою вакансією і впровадженими атомами азоту), які обмежуються атомами водню.

Розрахунки величин повної енергії оптимізованих просторових структур модельних кластерів $\mathrm{TiO}_{2} i$ відповідних теоретичних спектрів РФЕС виконані з використанням методу теорії функиіоналу густини (DFT) і гібридного функціоналу B3LYP з розширеним валентно-розщепленим базисним набором 6-31G $(d, p)$.

У РФЕС-спектрах O1s кожен пік може бути віднесений до певного типу атомів кисню в залежності від його координаційного оточення. Заміна атомами азоту атомів кисню призводить до ускладнення спектра. Одночасне заміщення атомами азоту атомів кисню і наявність кисневої вакансії призводять до подальшого ускладнення спектра РФЕС.

Розглянуто також різну будову адсорбиійних комплексів молекул води на поверхні анатазу, утворених завдяки водневому зв'язку НОН ․ (при иьому в спектрі РФЕС відбувається зсув на 0.05 еВ всіх піків), або координаиійної зв'язку Тi $\cdots \mathrm{OH}_{2}$.

На підставі аналізу теоретичних результатів розглянуто роль різних видів дефектів в адсорбиії води на поверхні анатазу. Теоретично одержсані результати порівнюються з властивостями молекулярних моделей для об 'єму і поверхні діоксиду титану, які існують у літературі.

Ключові слова: анатаз, спектри РФЕС, діоксид титану, метод теорії функиіоналу електронної густини, кластерні моделі

\section{Идентификация химического окружения молекул воды, адсорбированных на поверхности анатаза: квантовохимические расчеты}

\author{
А.В. Смирнова, А.Г. Гребенюк, В.В. Лобанов \\ Институт химии поверхности им. А.А. Чуйко Национальной академии наук Украины \\ ул. Генерала Наумова, 17, Киев, 03164, Украина, olsmirnova2001@ukr.net
}

Теоретические исследования взаимодействия молекульь кислорода с поверхностью твердой фазы имеют большое значение для понимания механизмов реакиий с участием $\mathrm{O}_{2}$ на твердой поверхности. В этой работе исследованы пространственное строение и электронная структура кислородных дефектов $u$ азотных примесных иенттов поверхности анатаза и их проявления в адсорбиии воды. Поверхность анатаза 
моделировалась кластерами состава $\mathrm{Ti}_{14} \mathrm{H}_{22} \mathrm{O}_{39}$ (бездефектная грань (001)), $\mathrm{Ti}_{14} \mathrm{H}_{22} \mathrm{O}_{38}$ (поверхность с кислородной вакансией) и $\mathrm{Ti}_{14} \mathrm{H}_{22} \mathrm{~N}_{2} \mathrm{O}_{36}$ (поверхность с кислородной вакансией и внедренными атомами азота), которые ограничены атомами водорода.

Расчеты величин полной энергии оптимизированных пространственных структур модельных кластеров $\mathrm{TiO}_{2}$ и соответствуюших теоретических спектров РФЭС выполнены с использованием метода теории функционала плотности (DFT) и гибридного функционала B3LYP с расщиренным валентно-расщепленным базисным набором 6-31G $(d, p)$.

В РФЭС-спектрах O1s каждый пик может быть отнесен к определенному типу атомов кислорода 8 зависимости от их координационного окружения. Замена атомами азота атомов кислорода приводит к усложнению спектра. Одновременное замещение атомами азота атомов кислорода и наличие кислородной вакансии приводят к дальнейшему усложнению спектра РФЭС.

Рассмотрено также различное строение адсорбционных комплексов молекул воды на поверхности анатаза, образованных благодаря водородной связи НОН $\cdots O$ (при этом в спектре РФЭС происходит смещение на 0,05 эВ всех пиков), или координационной связи $\mathrm{Ti}^{\cdots} \mathrm{OH}_{2}$.

На основании анализа теоретических результатов рассмотрена роль различных видов дефектов в адсорбции воды на поверхности анатаза. Теоретически полученные результатьл сравниваются со свойствами молекулярных моделей для объема и поверхности диоксида титана, имеющиеся в литературе.

Ключевые слова: анатаз, спектры РФЭС, диоксид титана, метод теории функиионала плотности, кластерные модели

\section{REFERENCES}

1. Trushina A.P., Goldort V.G., Kochubei S.A., Baklanov A.V. UV-photoexcitation of encounter complexes of oxygen $\mathrm{O}_{2}-\mathrm{O}_{2}$ as a source of singlet oxygen $\mathrm{O}_{2}\left({ }^{1} \Delta \mathrm{g}\right)$ in gas phase. Chem. Phys. Lett. 2010. 485(1-3): 11 .

2. Mo S., Ching W. Electronic and optical properties of three phases of titanium dioxide: Rutile, anatase and brookite. Phys. Rev. B. 1995. 51(19): 13023.

3. Anpo M., Shima T., Kodama S., Kubokawa Y. Photocatalytic hydrogenation of propyne with water on smallparticle titania: size quantization effects and reaction. J. Phys. Chem. 1987. 91(16): 4305.

4. Smirnova O., Grebenyuk A., Linnik O., Lobanov V. Quantum chemical study of water molecule adsorption on the nitrogen-doped titania thin films. Nanophysics, Nanomaterials, Interface Studies, and Applications: Selected Proc. $4^{\text {th }}$ Int. Conf. Nanotechnology and Nanomaterials (NANO2016, Aug. 24-27, 2016, Lviv, Ukraine. Springer, 2017): 603.

5. Sauer J. Molecular models in ab initio studies of solids and surfaces: from ionic crystals and semiconductors to catalysts. Chem. Rev. 1989. 89(1): 199.

6. Becke A. Density-functional thermochemistry. III. The role of exact exchange. J. Chem. Phys. 1993. 98(7): 5648.

7. Cohen A.J., Mori-Sanchez P, Yang W. Challenges for density functional theory. Chem. Rev. 2012. $112(1): 289$.

8. Schmidt M., Baldridge K., Boatz J., Elbert S., Gordon M., Jensen J., Koseki S., Matsunaga N., Nguyen K., Su S., Windus T., Dupuis M., Montgomery J. General atomic and molecular electronic structure system. J. Comput. Chem. 1993. 14(11): 1347.

9. Besogonov E.V., http://g-tools.narod.ru

10. Chobal A.I., Rizak I.M., Grebenyuk A.G., Rizak V.M. Electronic and spatial structure of nanoclusters of $\mathrm{Sn}_{2} \mathrm{P}_{2} \mathrm{~S}_{6}$ ferroelectric crystals. Phys. Solid State. 2010. 52(7): 1468. 